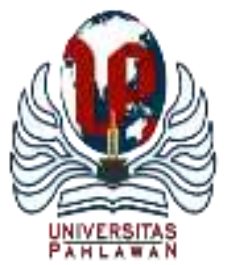

Edukatif : Jurnal Ilmu Pendidikan Volume 4 Nomor 1 Tahun 2022 Halm 707 - 714

EDUKATIF: JURNAL ILMU PENDIDIKAN

Research \& Learning in Education

https://edukatif.org/index.php/edukatif/index

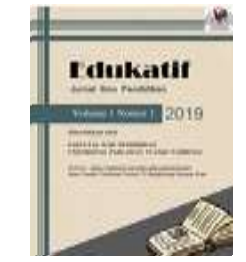

\title{
Analisis Tindak Tutur Perlokusi di Toko Alat Rumah Tangga Pasar Cibarusah Kabupaten Bekasi
}

\author{
Nukky Hervianty ${ }^{1 凶}$, Dian Hartati ${ }^{2}$, Roni Nugraha Syafroni ${ }^{3}$ \\ Universitas Singaperbangsa Karawang, Indonesia ${ }^{1,2,3}$

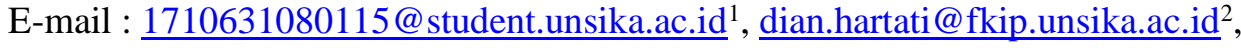 \\ roni.nugraha@fkip.unsika.ac.id ${ }^{3}$
}

\begin{abstract}
Abstrak
Penelitian ini berkenaan dengan tindak tutur perlokusi pedagang di toko Aneka Ilham Cibarusah dalam tindak tutur perlokusi yang dibagi menjadi dua jenis, diantaranya tindak tutur perlokusi verbal dan tindak tutur perlokusi verbal nonverbal. Tujuan penelitian untuk mendeskripsikan wujud tuturan, efek, dan fungsi tindak tutur perlokusi. Metode penelitian ini berpijak pada metode penelitian deskriptif, data yang diperoleh bukanlah berupa angka melainkan kata-kata dan kalimat. Hasil penelitian bentuk tindak tutur perlokusi verbal yang terdapat pada tuturan transaksi jual beli di Aneka Ilham. Informan Ida Deriyanti menuturkan lima tindak tutur perlokusi verbal. Informan Ujang Juhaedi menuturkan enam tindak tutur perlokusi verbal. Bentuk tindak tutur perlokusi verbal nonverbal yang terdapat pada tuturan transaksi jual beli di toko Aneka Ilham. Informan Ida Deriyanti menuturkan sepuluh tindak tutur perlokusi verbal nonverbal. Informan Ujang Juhaedi menuturkan enam tindak tutur perlokusi verbal nonverbal. Hasil penelitian ini dapat digunakan untuk menambah wawasan pengetahuan atau referensi untuk orang lain.
\end{abstract}

Kata Kunci: Pedagang, Tindak tutur perlokusi, Kualitatif-Deskriptif.

\begin{abstract}
Research on perlocutionary speech acts at Aneka Ilham Cibarusah store in perlocutionary speech acts, which are divided into two types, including verbal perlocutionary speech acts and nonverbal verbal perlocutionary speech acts. The purpose of the study was to describe the form of speech, effects, and functions of perlocutionary speech acts. This research method is based on descriptive research methods, the data obtained in the form of numbers but words and sentences. The results of the research in the form of verbal non-verbal behavior included in Aneka Ilham's sale and purchase transaction speech. Informant Ida Deryanti said that there were five perlocutionary speech acts. Informant Ujang Juhaedi said that there were six perlocutionary speech acts. Nonverbal verbal perlocutionary speech acts found in the speech of buying and selling transactions at the Aneka Ilham store. Informant Ida Deriyanti said ten speech acts of nonverbal perlocutionary verbal. Informant Ujang Juhaedi said that there were six perlocutionary verbal nonverbal speech acts. The results of this study can be used to add insight to knowledge or references for other people.
\end{abstract}

Keywords: Traders, Perlocutionary speech acts, Qualitative-Descriptive.

Copyright (c) 2022 Nukky Hervianty, Dian Hartati, Roni Nugraha Syafroni

$\triangle$ Corresponding author

Email : 1710631080115@student.unsika.ac.id _

DOI : https://doi.org/10.31004/edukatif.v4i1.1876

ISSN 2656-8063 (Media Cetak)

ISSN 2656-8071 (Media Online)

Edukatif : Jurnal Ilmu Pendidikan Vol 4 No 1 Tahun 2022 p-ISSN 2656-8063 e-ISSN 2656-8071 


\section{PENDAHULUAN}

Penggunaan tindak tutur dalam proses berniaga memiliki berbagai macam tindak tutur dan jenis tindak tutur di antaranya, tindak tutur perlokusi yang mempunyai daya pengaruh atau efek bagi pembeli yang mendengarkan mitra tutur terhadap efek yang di timbulkan setelah mendengar tuturan terbagi menjadi perlokusi verbal dan perlokusi verbal nonverbal.

Berdasarkan penelitian ini, peneliti akan menganalisis tindak tutur perlokusi yang mencakup wujud, efek, dan fungsi, khususnya pada tuturan dalam kegiatan negosiasi di lingkungan perdagangan. Peneliti akan mengumpulkan data secara sistematis dengan menyusun teori sesuai sasaran penelitian yaitu, pedagang di toko alat rumah tangga Aneka Ilham Cibarusah.

Menurut (Yule, 2006: 3) menyatakan bahwa, pragmatik adalah analisis terhadap tujuan pengujar. Secara terperinci, pragmatik merupakan suatu dialog yang berhubungan dengan makna tuturan yang disampaikan oleh penutur (penulis) dengan mempertimbangkan situasi dan kontekstual. Menurut Hymes dalam (Chaer Abdul, 2010: 48-49) mengkategorikan delapan komponen harus terpenuh dalam peristiwa tutur yaitu SPEAKING yang meliputi, setting and scene, participants, ends, act sequences, key, instrumentalities, norms of interaction and interpretation, genre. Setting and scene berkenaan dengan waktu dan tempat berlangsungnya peristiwa tutur. Tindak tutur adalah fenomena pragmatik yang berkenaan dengan tindakan penutur yang ditunjukkan melalui tuturan. Setiap tindak tutur memiliki penutur dan mitra tutur dalam proses komunikatifnya. Menurut (Yule, 2006: 82-84) tindak tutur merupakan tindakan-tindakan yang ditampilkan melalui tuturan biasanya disebut dengan tindak tutur. Jenis tindak tutur Menurut Searle (dalam (Wijana, 2009: 20) dalam bukunya Speech Acts An Essay in The Philosophy of Language mengemukakan bahwa secara pragmatis ada tiga jenis tindakan yang dapat diwujudkan oleh penutur, yakni, tindak lokusi (locutionary act), tindak ilokusi (ilocutionary act), dan tindak perlokusi (perlocutionary act). Menurut (Rahardi, 2009: 17) tindak tutur perlokusi merupakan tuturan yang disampaikan oleh penutur yang dapat memberikan efek ataupun pengaruh kepada mitra tutur. Oleh karena itu, efek atau daya pengaruh ini dapat terjadi karena disengaja ataupun tidak disengaja oleh penuturnya. Penggunaan tindak tutur perlokusi ditentukan oleh kemampuan penafsiran dari mitra tutur. Searle dalam (Angraini, 2020: 78) menyatakan bahwa tindak perlokusi dibagi menjadi tindak tutur perlokusi verbal dan tindak tutur perlokusi verbal nonverbal. Berdasarkan penelitian ini, mendeskripsikan wujud tuturan, efek, dan fungsi tindak tutur perlokusi pedagang di toko Aneka Ilham Cibarusah dalam tindak tutur perlokusi yang dibagi menjadi dua jenis, di antaranya tindak tutur perlokusi verbal dan tindak tutur perlokusi verbal nonverbal akan dijadikan bahan acuan penelitian selanjutnya dalam bidang pragmatik mengenai tindak tutur perlokusi.

Penggunaan tindak tutur perlokusi di toko alat rumah tangga Aneka Ilham Cibarusah perlu untuk diuji berdasarkan sudut pandang pragmatik, hal ini dikarenakan pemakaian tindak tutur perlokusi yang sulit untuk diidentifikasi yaitu, wujud, efek, dan fungsi tindak tutur perlokusi. Terkait dengan penelitian terdahulu, penelitian terdahulu meneliti tentang analisis jenis tindak tutur lokusi, ilokusi, dan perlokusi yang terdapat dalam komunikasi antara Penjual dan Pembeli di PASTY, sedangkan kebaruan pada penelitian ini dengan meneliti wujud dan fungsi tindak tutur perlokusi yang terdapat dalam komunikasi antara penjual dan pembeli di toko alat rumah tangga.

\section{METODE PENELITIAN}

Pendekatan penelitian yang akan digunakan di dalam penelitian ini ialah pendekatan kualitatif. Pendekatan kualitatif merupakan pendekatan yang tepat untuk memahami suatu fenomena sosial dan perspektif (sudut pandang) individu yang akan diteliti. Menurut Bodgan dan Taylor dalam (J. Moleong, 2014: 4) penelitian kualitatif merupakan prosedur yang menghasilkan data deskriptif berupa kata-kata yang tertulis 
atau lisan pada perilaku manusia. Berdasarkan permasalahan dan pendekatan penelitian, penelitian ini berpijak pada metode deskriptif, data yang diperoleh bukanlah berupa angka melainkan kata-kata dan kalimat. Menurut (Nawawi, 2012: 67) metode deskriptif memiliki sebuah prosedur untuk memecahkan masalah yang diteliti dengan mendeskripsikan keadaan subyek atau obyek penelitian (seseorang lembaga dan lain-lain) dengan fakta yang tampak atau apa adanya.

Penentuan besar subjek penelitian didasarkan pada permasalahan yang akan diteliti tentang wujud dan fungsi tindak tutur perlokusi pedagang. Berdasarkan pengertian tersebut maka dalam penelitian ini subjek penelitian adalah informan yang berinteraksi dalam kegiatan berniaga antara pedagang dan pembeli di Toko Aneka Ilham Cibarusah. Maka, besar subjek di dalam penelitian ini yaitu. Maka, besar subjek penelitian yaitu dua informan. Informan Ida Deriyanti dan informan Ujang Juhaedi dalam menuturkan tindak tutur perlokusi verbal dan verbal nonverbal.

Tahap terpenting dalam sebuah penelitian adalah pengumpulan data. Pengumpulan merupakan suatu proses pengadaan data untuk kebutuhan penelitian. Pengumpulan data adalah pengujian terhadap kemampuan peneliti dalam penguasaan teori struktur yang menjadi landasan dalam melaksanakan suatu penelitian. Teknik pengumpulan data pada pokok permasalahan. Adapun teknik pengumpulan data yang akan dilakukan di dalam penelitian ini, yaitu teknik pengamatan, teknik perekaman, dan teknik catat.

Teknik analisis data yang digunakan dalam pengumpulan data pada penelitian ini ialah teknik analisis deskriptif kualitatif. Data yang dikumpulkan dalam penelitian bahasa ini ialah berupa kata-kata. Oleh karena itu, penelitian bahasa ini harus melihat gejala yang ada sesuai dengan kenyataan agar deskripsi yang dibuatnya akan sangat bermakna karena berupa pendeskripsian yang disesuaikan dengan kenyataan yang ada. Tahap analisis selanjutnya adalah pendeskripsian menggunakan kode berdasarkan data, kode data, jam, informan, peristiwa tutur, konteks, bentuk tindak tutur perlokusi, dan fungsi tindak tutur perlokusi. Data (Data 1) berupa data transkrip wujud tuturan perlokusi, Kode Data (KD) berupa kode dari tanggal, bulan, tahun, dan nomor data (KD : 17/Agustus/2021/D-1), Jam (J) waktu atau jam data di ambil, Informan (I) pedagang sebagai informan, Peristiwa tutur mendeskripsikan peristiwa pada situasi tuturan ketika data di ambil, Konteks (K) berupa makna tuturan perlokusi, bentuk tindak tutur perlokusi (BTTP), berupa bentuk tindak tutur perlokusi yang terdiri dari penggunaan jenis tindak tutur perlokusi verbal dan perlokusi verbal nonverbal, fungsi Tindak Tutur Perlokusi (FTTP) berupa fungsi tindak tutur perlokusi yang meliputi, fungsi kompetitif, fungsi menyenangkan, fungsi bekerja sama, fungsi menantang.

\section{HASIL DAN PEMBAHASAN PENELITIAN}

Cibarusah merupakan sebuah kecamatan yang berlokasi di Kabupaten Bekasi. Cibarusah merupakan sebuah wilayah yang strategis dikarenakan dekat dengan wilayah pemukiman, pertanian, pemerintahan, serta dekat dengan wilayah kawasan industri yang berlokasi di cikarang. Dikarenakan lokasinya yang strategis, maka banyak sekali para pendatang yang bermukim di wilayah Cibarusah. Oleh karena itu, Dengan adanya pasar tradisional yang di kenal dengan pasar cibarusah maka dapat dijadikan sebagai tempat berbelanja masyarakat guna untuk memenuhi kebutuhan sehari-hari. Di Pasar Cibarusah terdapat beberapa toko yang menjual berbagai kebutuhan yang dibutuhkan oleh masyarakat seperti, toko sembako, toko onderdeal, toko alat rumah tangga, toko elektronik, toko pakaian, toko mebel, apotik, dan lainnya.

Toko Aneka Ilham merupakan sebuah toko yang menjual peralatan rumah tangga dan sepeda. Toko Aneka Ilham berlokasi di Desa Cibarusah, Kecamatan Cibarusah, Kabupaten Bekasi, Provinsi Jawa Barat, kode pos 17341 yang letaknya di depan Pasar Cibarusah. Pendiri toko Aneka Ilham ialah Ida Deriyanti yang mendirikan Toko Aneka Ilham sejak tahun 1985 dengan tujuan untuk memenuhi kebutuhan alat rumah tangga yang diperlukan oleh masyarakat. Toko Aneka Ilham dalam menjalankan aktifitas berniaga buka di pagi hari pukul 06.25 WIB dan tutup di sore hari pukul 17.10 WIB, sedangakan untuk di hari minggu Toko Aneka 
710 Analisis Tindak Tutur Perlokusi di Toko Alat Rumah Tangga Pasar Cibarusah Kabupaten Bekasi - Nukky

Hervianty, Dian Hartati, Roni Nugraha Syafroni

DOI

: https://doi.org/10.31004/edukatif.v4i1.1876

Ilham tidak menjalankan aktifitas berniaga dikarenakan libur. Situasi umum di Toko Aneka Ilham pada saat ini masyarakatnya dominan menggunakan bahasa Sunda dan bahasa Indonesia sebagai alat untuk berkomunikasi dalam kegiatan berniaga.

Pelaksanaan penelitian ini dilakukan dalam waktu lima bulan, di mulai pada bulan Juni 2021 sampai Desember 2021. Adapun jadwal penelitian sebagai berikut:

Tabel 1 Jadwal Penelitian Kualitatif

\begin{tabular}{|c|c|c|c|c|c|c|c|c|c|c|c|}
\hline \multirow[b]{2}{*}{$\begin{array}{l}\text { Keterangan atau } \\
\text { bulan }\end{array}$} & \multicolumn{11}{|c|}{2021} \\
\hline & $\begin{array}{l}\text { Februa } \\
\text { ri }\end{array}$ & $\begin{array}{l}\text { Mar } \\
\text { et }\end{array}$ & $\begin{array}{l}\text { Apri } \\
1\end{array}$ & Mei & Juni & Juli & $\begin{array}{l}\text { Agus } \\
\text { tus }\end{array}$ & $\begin{array}{l}\text { Septe } \\
\text { mber }\end{array}$ & $\begin{array}{l}\text { Okto } \\
\text { ber }\end{array}$ & $\begin{array}{l}\text { Nove } \\
\text { mber }\end{array}$ & $\begin{array}{l}\text { Dese } \\
\text { mber }\end{array}$ \\
\hline $\begin{array}{l}\text { Penyusunan } \\
\text { Proposal }\end{array}$ & & & & & & & & & & & \\
\hline $\begin{array}{l}\text { Perizinan } \\
\text { Penelitian }\end{array}$ & & & & & & & & & & & \\
\hline $\begin{array}{l}\text { Pengumpulan } \\
\text { Data }\end{array}$ & & & & & & & & & & & \\
\hline $\begin{array}{l}\text { Penyusunan } \\
\text { Laporan } \\
\text { Penelitian }\end{array}$ & & & & & & & & & & & \\
\hline
\end{tabular}

Tahap pengumpulan data di dalam penelitian ini, peneliti melakukan penelitian di Desa Cibarusah, Kecamatan Cibarusah, Kabupaten Bekasi, Provinsi Jawa Barat, kode pos 17341 dengan tujuan untuk menganalisis tindak tutur perlokusi. Dapat diketahui masyarakat yang berdomisili di daerah cibarusah pada umumnya menggunakan bahasa Indonesia, bahasa jawa dan bahasa sunda dalam berkomunikasi. Akan tetapi, bahasa yang dominan digunakan oleh masyarakat cibarusah saat berinteraksi dalam kegiatan berniaga di Pasar Cibarusah ialah bahasa Indonesia dan bahasa sunda, hal ini dikarenakan sebagian besar masyarakat yang berdomisili di daerah Cibarusah adalah suku sunda. Oleh karena itu, untuk memudahkan pembaca dalam memahami kalimat yang dituturkan oleh pedagang dan pembeli, maka peneliti menerjemahkan kalimat yang menggunakan bahasa sunda ke dalam bahasa Indonesia serta menggunakan tanda kurung sebagai pembeda agar pembaca dapat memahami kalimat yang telah diterjemahkan.

Pembahasan data hasil penelitian ini dilaksanakan dengan menjaring data yang telah terkumpul di dalam transkrip dialog antara pedangang (mitra tutur) dan pembeli (penutur) dengan memilih data yang akan dikelompokkan berdasarkan tuturan yang mengandung tindak tutur perlokusi serta fungsi dari tuturan tersebut. Deskripsi data tindak tutur perlokusi yang terbagi dua yaitu, tindak tutur perlokusi verbal dan verbal nonverbal. Berikut ini adalah deskripsi pembahasan hasil penelitian yang berkaitan dengan penggunaan jenis tindak tutur perlokusi verbal dan verbal nonverbal beserta fungsinya pada tuturan pedagang dalam transaksi jual beli di toko Aneka Ilham.

Berdasarkan rangkaian analisis data bentuk dan fungsi tindak tutur perlokusi di toko Aneka Ilham dalam menggunakan tindak tutur perlokusi. Berikut ini adalah tabel hasil temuan tindak tutur perlokusi pada tuturan pedagang dalam transaksi jualbeli di toko Aneka Ilham.

Tabel 2 Hasil temuan bentuk dan fungsi tindak tutur perlokusi

\begin{tabular}{llllll}
\hline No & Data & Tanggal dan Jam & Informan & $\begin{array}{c}\text { Bentuk } \\
\text { Tindak } \\
\text { Tutur } \\
\text { Perlokusi }\end{array}$ & $\begin{array}{c}\text { Fungsi Tindak Tutur } \\
\text { Perlokusi }\end{array}$ \\
\hline 1 & Data 1 & $\begin{array}{l}\text { 2/Agustus/2021 } \\
15.00 \mathrm{WIB}\end{array}$ & Ida Deriyanti & Verbal & Fungsi kompetitif (meminta) \\
\hline
\end{tabular}


711 Analisis Tindak Tutur Perlokusi di Toko Alat Rumah Tangga Pasar Cibarusah Kabupaten Bekasi - Nukky Hervianty, Dian Hartati, Roni Nugraha Syafroni

\begin{tabular}{|c|c|c|c|c|c|}
\hline No & Data & Tanggal dan Jam & Informan & $\begin{array}{c}\text { Bentuk } \\
\text { Tindak } \\
\text { Tutur } \\
\text { Perlokusi }\end{array}$ & $\begin{array}{c}\text { Fungsi Tindak Tutur } \\
\text { Perlokusi }\end{array}$ \\
\hline 2 & Data 2 & $\begin{array}{l}\text { 3/Agustus/2021 } \\
13.26 \mathrm{WIB}\end{array}$ & Ida Deriyanti & $\begin{array}{l}\text { Verbal } \\
\text { Nonverbal }\end{array}$ & $\begin{array}{l}\text { Fungsi bekerja sama } \\
\text { (menyatakan) }\end{array}$ \\
\hline 3 & Data 3 & $\begin{array}{l}\text { 4/Agustus/2021 } \\
10.14 \mathrm{WIB}\end{array}$ & Ujang Juhaedi & $\begin{array}{l}\text { Verbal } \\
\text { Nonverbal }\end{array}$ & $\begin{array}{l}\text { Fungsi bekerja sama } \\
\text { (menyatakan) }\end{array}$ \\
\hline 4 & Data 4 & $\begin{array}{l}\text { 5/Agustus/2021 } \\
14.25 \text { WIB }\end{array}$ & Ida Deriyanti & $\begin{array}{l}\text { Verbal } \\
\text { Nonverbal }\end{array}$ & $\begin{array}{l}\text { Fungsi bekerja sama } \\
\text { (menyatakan) }\end{array}$ \\
\hline 5 & Data 5 & $\begin{array}{l}\text { 6/Agustus/2021 } \\
08.15 \text { WIB }\end{array}$ & Ida Deriyanti & $\begin{array}{l}\text { Verbal } \\
\text { Nonverbal }\end{array}$ & Fungsi kompetitif (menolak) \\
\hline 6 & Data 6 & $\begin{array}{l}\text { 7/Agustus/2021 } \\
14.33 \mathrm{WIB}\end{array}$ & Ida Deriyanti & $\begin{array}{l}\text { Verbal } \\
\text { Nonverbal }\end{array}$ & Fungsi kompetitif (memerintah) \\
\hline 7 & Data 7 & $\begin{array}{l}\text { 9/Agustus/2021 } \\
09.08 \text { WIB }\end{array}$ & Ujang Juhaedi & Verbal & $\begin{array}{l}\text { Fungsi bekerja sama } \\
\text { (menyatakan) }\end{array}$ \\
\hline 8 & Data 8 & $\begin{array}{l}\text { 10/Agustus/2021 } \\
15.49 \mathrm{WIB}\end{array}$ & Ida Deriyanti & Verbal & $\begin{array}{l}\text { Fungsi menyenangkan } \\
\text { (menawarkan) }\end{array}$ \\
\hline 9 & Data 9 & $\begin{array}{l}\text { 11/Agustus/2021 } \\
12.39 \mathrm{WIB}\end{array}$ & Ida Deriyanti & Verbal & $\begin{array}{l}\text { Fungsi menyenangkan } \\
\text { (menawarkan) }\end{array}$ \\
\hline 10 & Data 10 & $\begin{array}{l}\text { 12/Agustus/2021 } \\
\text { 16.37 WIB }\end{array}$ & Ujang Juhaedi & $\begin{array}{l}\text { Verbal } \\
\text { Nonverbal }\end{array}$ & $\begin{array}{l}\text { Fungsi bekerja sama } \\
\text { (menyatakan) }\end{array}$ \\
\hline 11 & Data 11 & $\begin{array}{l}\text { 13/Agustus/2021 } \\
\text { 10.14 WIB }\end{array}$ & Ida Deriyanti & $\begin{array}{l}\text { Verbal } \\
\text { Nonverbal }\end{array}$ & $\begin{array}{l}\text { Fungsi menyenangkan } \\
\text { (menawarkan) }\end{array}$ \\
\hline 12 & Data 12 & $\begin{array}{l}\text { 14/Agustus/2021 } \\
08.23 \mathrm{WIB}\end{array}$ & Ujang Juhaedi & $\begin{array}{l}\text { Verbal } \\
\text { Nonverbal }\end{array}$ & $\begin{array}{l}\text { Fungsi bekerja sama } \\
\text { (menyatakan) }\end{array}$ \\
\hline 13 & Data 13 & $\begin{array}{l}\text { 16/Agustus/2021 } \\
\text { 13.35 WIB }\end{array}$ & Ujang Juhaedi & Verbal & Fungsi kompetitif (menolak) \\
\hline 14 & Data 14 & $\begin{array}{l}\text { 17/Agustus/2021 } \\
11.08 \mathrm{WIB}\end{array}$ & Ujang Juhaedi & Verbal & $\begin{array}{l}\text { Fungsi bekerja sama } \\
\text { (menyatakan) }\end{array}$ \\
\hline 15 & Data 15 & $\begin{array}{l}\text { 18/Agustus/2021 } \\
\text { 16.11 WIB }\end{array}$ & Ujang Juhaedi & Verbal & $\begin{array}{l}\text { Fungsi menyenangkan } \\
\text { (menawarkan) }\end{array}$ \\
\hline 16 & Data 16 & $\begin{array}{l}\text { 19/Agustus/2021 } \\
11.40 \mathrm{WIB}\end{array}$ & Ujang Juhaedi & Verbal & $\begin{array}{l}\text { Fungsi bekerja sama } \\
\text { (menyatakan) }\end{array}$ \\
\hline 17 & Data 17 & $\begin{array}{l}\text { 20/Agustus/2021 } \\
\text { 15.47 WIB }\end{array}$ & Ida Deriyanti & $\begin{array}{l}\text { Verbal } \\
\text { Nonverbal }\end{array}$ & $\begin{array}{l}\text { Fungsi menyenangkan } \\
\text { (menawarkan) }\end{array}$ \\
\hline 18 & Data 18 & $\begin{array}{l}\text { 21/Agustus/2021 } \\
14.53 \mathrm{WIB}\end{array}$ & Ida Deriyanti & $\begin{array}{l}\text { Verbal } \\
\text { Nonverbal }\end{array}$ & $\begin{array}{l}\text { Fungsi menyenangkan } \\
\text { (menawarkan) }\end{array}$ \\
\hline 19 & Data 19 & $\begin{array}{l}\text { 23/Agustus/2021 } \\
12.25 \mathrm{WIB}\end{array}$ & Ida Deriyanti & Verbal & $\begin{array}{l}\text { Fungsi bekerja sama } \\
\text { (menyatakan) }\end{array}$ \\
\hline 20 & Data 20 & $\begin{array}{l}\text { 24/Agustus/2021 } \\
11.16 \text { WIB }\end{array}$ & Ujang Juhaedi & $\begin{array}{l}\text { Verbal } \\
\text { Nonverbal }\end{array}$ & $\begin{array}{l}\text { Fungsi menyenangkan } \\
\text { (menawarkan) }\end{array}$ \\
\hline 21 & Data 21 & $\begin{array}{l}\text { 25/Agustus/2021 } \\
08.40 \mathrm{WIB}\end{array}$ & Ujang Juhaedi & $\begin{array}{l}\text { Verbal } \\
\text { Nonverbal }\end{array}$ & $\begin{array}{l}\text { Fungsi menyenangkan } \\
\text { (menawarkan) }\end{array}$ \\
\hline 22 & Data 22 & $\begin{array}{l}\text { 26/Agustus/2021 } \\
14.37 \mathrm{WIB}\end{array}$ & Ida Deriyanti & $\begin{array}{l}\text { Verbal } \\
\text { Nonverbal }\end{array}$ & Fungsi kompetitif (memerintah) \\
\hline 23 & Data 23 & $\begin{array}{l}\text { 27/Agustus/2021 } \\
11.45 \mathrm{WIB}\end{array}$ & Ujang Juhaedi & $\begin{array}{l}\text { Verbal } \\
\text { Nonverbal }\end{array}$ & Fungsi kompetitif (memerintah) \\
\hline 24 & Data 24 & $\begin{array}{l}\text { 28/Agustus/2021 } \\
\text { 13.53 WIB }\end{array}$ & Ida Deriyanti & Verbal & Fungsi kompetitif (memerintah) \\
\hline 25 & Data 25 & $\begin{array}{l}\text { 30/Agustus/2021 } \\
08.13 \mathrm{WIB}\end{array}$ & Ida Deriyanti & $\begin{array}{l}\text { Verbal } \\
\text { Nonverbal }\end{array}$ & $\begin{array}{l}\text { Fungsi menyenangkan } \\
\text { (menawarkan) }\end{array}$ \\
\hline
\end{tabular}


712 Analisis Tindak Tutur Perlokusi di Toko Alat Rumah Tangga Pasar Cibarusah Kabupaten Bekasi - Nukky

Hervianty, Dian Hartati, Roni Nugraha Syafroni

DOI : https://doi.org/10.31004/edukatif.v4i1.1876

\begin{tabular}{llllll}
\hline No & Data & Tanggal dan Jam & Informan & $\begin{array}{c}\text { Bentuk } \\
\text { Tindak } \\
\text { Tutur } \\
\text { Perlokusi }\end{array}$ & $\begin{array}{c}\text { Fungsi Tindak Tutur } \\
\text { Perlokusi }\end{array}$ \\
\hline 26 & Data 26 & $\begin{array}{l}\text { 31/Agustus/2021 } \\
11.39 \text { WIB }\end{array}$ & Ujang Juhaedi & Verbal & Fungsi menyenangkan (merayu) \\
\hline
\end{tabular}

Berdasarkan rangkaian analisis data bentuk dan fungsi tindak tutur perlokusi di toko Aneka Ilham dalam menggunakan tindak tutur perlokusi. Berikut ini adalah tabel hasil temuan bentuk dan fungsi tindak tutur perlokusi pada tuturan pedagang dalam transaksi jualbeli di toko Aneka Ilham.

Tabel 3 Hasil analisis bentuk dan fungsi tindak tutur perlokusi

\begin{tabular}{lclll}
\hline \multirow{2}{*}{ No. } & \multirow{2}{*}{ Informan } & \multicolumn{1}{c}{ Tuturan } & $\begin{array}{c}\text { Bentuk Tindak } \\
\text { Tutur Perlokusi }\end{array}$ & \multicolumn{1}{c}{ Fungsi Tindak Tutur Perlokusi } \\
\hline 1 & Ida Deriyanti & $\begin{array}{l}\text { Tindak Tutur } \\
\text { Perlokusi } \\
\text { Verbal }\end{array}$ & $\begin{array}{l}\text { 5 Tindak tutur } \\
\text { perlokusi verbal }\end{array}$ & $\begin{array}{l}\text { 2 Fungsi kompetitif (memerintah dan } \\
\text { meminta) }\end{array}$ \\
\cline { 4 - 5 } & & & 1 Fungsi bekerja sama (menyatakan) \\
\cline { 4 - 5 } & & & 2 Fungsi menyenangkan (menawarkan)
\end{tabular}

\begin{tabular}{lll}
\hline $\begin{array}{l}\text { Tindak tutur } \\
\text { perlokusi }\end{array}$ & $\begin{array}{l}\text { 10 Tindak tutur } \\
\text { perlokusi verbal } \\
\text { verbal }\end{array}$ & $\begin{array}{l}\text { 3 Fungsi kompetitif (memerintah dan } \\
\text { menolak) }\end{array}$ \\
nonverbal & & 2 Fungsi bekerja sama (menyatakan) \\
\cline { 3 - 3 } & & 4 Fungsi menyenangkan (menawarkan)
\end{tabular}

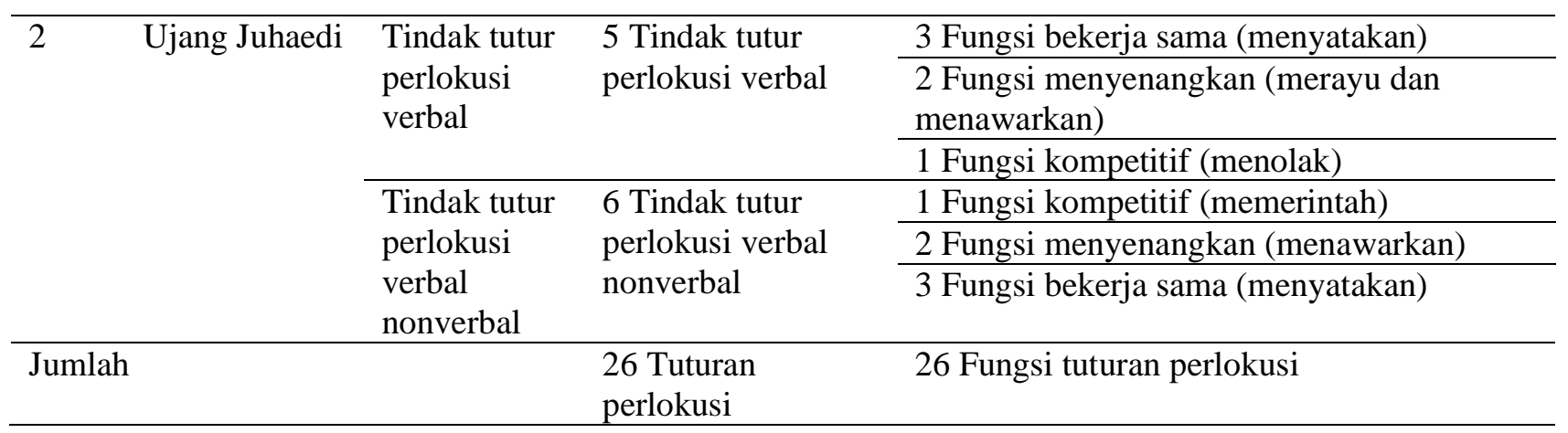

Berdasarkan rangkaian data analisis tindak tutur perlokusi di toko Aneka Ilham dalam peristiwa tindak tutur perlokusi. Berikut ini adalah deskripsi peristiwa tindak tutur perlokusi dalam transaksi jual beli di toko Aneka Ilham. Peristiwa tutur yang terjadi selama satu bulan di toko Aneka Ilham sejak tanggal 2 Agustus 2021 sampai dengan 31 Agustus 2021 terkumpul dua puluh enam tuturan perlokusi dalam transaksi jual beli di toko Aneka Ilham.

Selama empat pekan peneliti mengamati peristiwa tutur yang terjadi di awal bulan lebih dominan percakapan antara pedagang dan pembeli, sementara di akhir bulan lebih dominan percakapan antara pedagang dan karyawan. Peristiwa tutur yang dominan di akhir bulan akibat stok barang yang sudah terjual sejak awal bulan dan pedagang menerima order barang masuk di akhir bulan untuk mengisi kekosongan stok barang. 
Peristiwa tutur berdasarkan jam selama empat pekan di toko Aneka Ilham sejak tanggal 2 Agustus 2021 sampai dengan 31 Agustus 2021. Peristiwa tutur pada pagi hari menuju siang hari di dominasi informan Ujang Juhaedi dan pada siang hari menuju sore hari di dominasi informan Ida Deriyanti. Informan pedagang dalam menjual aneka alat rumah tangga berdasarkan waktu dan jam selama empat pekan di toko Aneka Ilham sejak tanggal 2 Agustus 2021 sampai dengan 31 Agustus 2021. Pagi hari menjadi langkah awal berdagang untuk menjaga harga. Siang hari menjadi pilihan pedagang untuk memanfaatkan waktu jika tidak ada pelanggan untuk memberikan kode pada stok barang dan menyusun barang. Siang menuju ke sore hari pedagang sudah tidak menahan harga jual dan menerima penawaran penjual.

Berdasarkan rangkaian data analisis tindak tutur perlokusi di toko Aneka Ilham dalam menggunakan tindak tutur perlokusi seperti tindak tutur perlokusi verbal dan verbal nonverbal. Berikut ini adalah deskripsi bentuk tindak tutur perlokusi pada tuturan pedagang dalam transaksi jual beli di toko Aneka Ilham. Bentuk tindak tutur perlokusi verbal yang terdapat pada tuturan transaksi jual beli di Aneka Ilham.

Informan Ida Deriyanti menuturkan lima tindak tutur perlokusi verbal. Informan Ujang Juhaedi menuturkan enamlima tindak tutur perlokusi verbal. Bentuk tindak tutur perlokusi verbal nonverbal yang terdapat pada tuturan transaksi jual beli di toko Aneka Ilham. Informan Ida Deriyanti menuturkan sepuluh tindak tutur perlokusi verbal nonverbal.

Informan Ujang Juhaedi menuturkan enam tindak tutur perlokusi verbal nonverbal. Berdasarkan rangkaian analisis data bentuk dan fungsi tindak tutur perlokusi di toko Aneka Ilham dalam menggunakan tindak tutur perlokusi. Berikut ini adalah tabel hasil temuan bentuk dan fungsi tindak tutur perlokusi pada tuturan pedagang dalam transaksi jual beli di toko Aneka Ilham.

\section{KESIMPULAN}

Penelitian tindak tutur perlokusi pedagang di toko Aneka Ilham Cibarusah dalam tindak tutur perlokusi yang dibagi menjadi dua jenis, di antaranya tindak tutur perlokusi verbal dan tindak tutur perlokusi verbal nonverbal dengan tujuan penelitian untuk mendeskripsikan wujud tuturan, efek, dan fungsi tindak tutur perlokusi. Penelitian ini berpijak pada metode deskriptif, data yang diperoleh berdasarkan rangkaian data analisis tindak tutur perlokusi di toko Aneka Ilham dalam peristiwa tindak tutur perlokusi terdapat informan Ida Deriyanti menuturkan sepuluh tindak tutur perlokusi verbal nonverbal dan informan Ujang Juhaedi menuturkan enam tindak tutur perlokusi verbal nonverbal.

\section{UCAPAN TERIMA KASIH}

Penulis menyadari bahwa dalam penulisan artikel ini tidak dapat terselesaikan dengan baik tanpa adanya dukungan dari berbagai pihak. Oleh karena itu, penulis mengucapkan terima kasih kepada dosen pembimbing yang sudah memberikan motivasi, kedua orang tua serta kakak saya yang senantiasa memanjatkan doa, dukungan, dan semangat selama penyusunan artikel penelitian ini. Akhir kata penulis berharap semoga artikel ini bermanfaat dan tepat guna bagi pembaca dan pihak lain yang mempunyai kepentingan sama.

\section{DAFTAR PUSTAKA}

Angraini, Novita. 2020. "Bentuk Tindak Tutur Lokusi Dan Ilokusi Pedagang Dan Pembeli Di Pasar Sekip Ujung, $\quad$ Palembang." Jurnal Bidar $\quad 10(1)$ : Https://Ojs.Badanbahasa.Kemdikbud.Go.Id/Jurnal/Index.Php/Bidar/\%0aarticle/View/3069.

Chaer Abdul, Agustina Leoni. 2010. Sosiolinguistik: Perkenalan Awal. Jakarta: Pt Rineka Cipta. 
714 Analisis Tindak Tutur Perlokusi di Toko Alat Rumah Tangga Pasar Cibarusah Kabupaten Bekasi - Nukky Hervianty, Dian Hartati, Roni Nugraha Syafroni

DOI : https://doi.org/10.31004/edukatif.v4i1.1876

Evita Sholeha Pra Yoga. 2017. "Tindak Perlokusi Dalam Percakapan Antarsiswa Kelas Vii Smp Muhammadiyah Ahmad Dahlan Metro.” Jurnal Kata (Bahasa, Sastra, Dan Pembelajarannya) 5(4): 110.

Haryani, Febri. 2020. “Tindak Tutur Perlokusi Dalam Dialog Film 'The Teacher's Diary' Dengan Subtitle Bahasa Indonesia.” Jurnal Skripta 6(2): 16-25.

Haviz Noval Haidar. 2021. "Analisis Tindak Tutur Ilokusi Direktif Pedagang Di Toko Mujur Motor Cibarusah Kota." Edukatif: Jurnal Ilmu Pendidikan 3(5): 3244-53.

I Made Pradipta Adhiguna. 2019. "Analisis Tindak Tutur Lokusi, Ilokusi, Dan Perlokusi Dalam Proses Pembelajaran Bahasa Indonesia Di Kelas Xi Mipa 7 Sma N 7 Denpasar Tahun Pelajaran 2018/2019." Jurnal Bakti Saraswati 8(2): 204-11.

J. Moleong, Lexy. 2014. Metode Penelitian Kualitatif, Edisi Revisi. Bandung: Remaja Rosdakarya.

Liya Umaroh. 2017. "Dominasi Ilokusi Dan Perlokusi Dalam Transaksi Jual Beli." Lensa: Kajian Kebahasaan, Kesusastraan, Dan Budaya 7(1): 21-33.

Mariana Helga Eka Septiana. 2020. "Analisis Tindak Tutur Lokusi, Ilokusi, Perlokusi Pada Dialog Film 5cm Karya Rizal Mantovani (Sebuah Tinjauan Pragmatik).” Jurnal Ilmiah Pendidikan Bahasa Dan Sastra Indonesia (Jipbsi) 1(1): 98-104.

Muhammad Yunus. 2019. “Tindak Tutur Interaksi Jual Beli Di Pasar Lama Banjarmasin.” Idealektik 1(1): 1520.

Nadzifah, Zulfa Naurah. 2020. “Tindak Tutur Perlokusi Pada Dialog Film 'Keluarga Cemara' Karya Yandy Laurens.” Dinamika: Jurnal Bahasa, Sastra, Dan Pembelajarannya 3(2): 44-51.

Nawawi, Hadari. 2012. Metode Penelitian Bidang Sosial. Yogyakarta: Gajah Mada University Press.

Nisa, Choirun. 2019. "Analisis Tindak Tutur Penjual Dan Pembeli Di Pasar Pabean." Jurnal Ilmiah Pendidikan Bahasa Dan Sastra Indonesia 5(2): 49-55.

Pindha Kaptiningrum. 2020. "Analisis Tindak Tutur Lokusi, Ilokusi Dan Perlokusi Pada Whatsapp Group Sivitas Akademika Ibn Tegal.” Lingua: Jurnal Bahasa, Sastra, Dan Pengajarannya 17(1): 95-101.

Rahardi, Kunjana. 2008. Pragmatik: Kesantunan Imperatif Bahasa Indonesia. Jakarta: Erlangga. 2009. Sosiopragmatik. Jakarta: Erlangga.

Rahmayani. 2021. "Analisis Tindak Tutur Ilokusi Pada Caption Instagram Tokopedia Serta Pemanfaatannya Sebagai Bahan Ajar Teks Persuasi Di Sekolah Menengah Pertama." Edukatif: Jurnal Ilmu Pendidikan 3(6): 4290-98.

Raihan Nurfadhila. 2021. "Analisis Tindak Tutur Dalam Novel Kembara Rindu Karya Habiburrahman El Shirazy.” Bahastrajurnal Pendidikan Bahasa Dan Sastra Indonesia 6(1): 98-110.

Sari, Annisa Tri. 2017. "Analisis Tindak Tutur Dalam Dialog Ahok Dengan Masyarakat Di Pulau Seribu." Jurnal Edukasi Kultura: Jurnal Bahasa, Sastra Dan Budaya 4(1): 1-21.

Tuti Hidayah. 2020. "Analisis Tindak Tutur Lokusi, Ilokusi, Dan Perlokusi Pada Film 'Papa Maafin Risa." Parole (Jurnal Pendidikan Bahasa Dan Sastra Indonesia) 3(1): 71-79.

Wahyu Oktavia. 2019. “Tindak Tutur Perlokusi Dalam Album Lirik Lagu Iwan Fals: Relevansinya Terhadap Pembentukan Karakter.” Lingua: Jurnal Bahasa, Sastra, Dan Pengajarannya 15(1): 1-10.

Wijana, Muhammad Rohmadi. 2009. Analisis Wacana Pragmatik Kajian Teori Dan Analisis. Surakarta: Yuma Pustaka.

Yule, George. 2006. Pragmatik. Yogyakarta: Pustaka Pelajar. 